\title{
Frequency of the LRRK2 G2019S mutation in late-onset sporadic patients with Parkinson's disease
}

\author{
Frequência da mutação G2019S do LRRK2 em pacientes com doença de Parkinson \\ esporádica e início tardio
}

Hsin Fen Chien', Tamires Rocha Figueiredo', Marianna Almeida Hollaender ${ }^{1}$, Fabiano Tofoli², Leonel Tadao Takada1, Lygia da Veiga Pereira², Egberto Reis Barbosa ${ }^{1}$

\begin{abstract}
Mutations in the LRRK2 gene, predominantly G2019S, have been reported in individuals with autosomal dominant inheritance and sporadic Parkinson's disease (PD). The G2019S mutation has an age-dependent penetrance and evidence shows common ancestry. The clinical manifestations are indistinguishable from idiopathic PD. Its prevalence varies according to the population studied ranging from less than $0.1 \%$ in Asians to $41 \%$ in North African Arabs. This study aimed to identify G2019S mutation in Brazilian idiopathic PD patients. Method: We sampled 100 PD patients and 100 age- and gender-matched controls. Genetical analysis was accomplished by polymerase chain reaction (PCR). Results: No G2019S mutations were found in both patients with sporadic PD and controls. Conclusions: Our results may be explained by the relatively small sample size.
\end{abstract}

Keywords: Parkinson's disease, LRRK2, genetics.

\section{RESUMO}

Mutação no gene LRRK2, predominantemente G2019S, foi descrita em indivíduos com doença de Parkinson (DP) esporádica ou herança autossômica dominante. A penetrância da mutação varia com a idade e há evidências de ancestral comum. As manifestações clínicas são indistinguiveis da DP idiopática. Sua prevalência depende da população estudada e varia de 0,1\% em asiáticos a 41\% em árabes do norte africano. O objetivo desse estudo foi identificar a mutação G2019S em brasileiros com DP esporádica. Método: Foram testados 100 pacientes com DP e 100 controles pareados por idade e sexo. A análise genética foi realizada pela reação em cadeia por polimerização (PCR). Resultados: Não foi encontrada a mutação G2019S nem nos pacientes com DP nem nos controles. Conclusão: É possível que nossos resultados sejam devidos ao pequeno número de pacientes incluídos.

Palavras-chave: doença de Parkinson, LRRK2, genética.

\section{INTRODUCTION}

Parkinson's disease (PD) is the second most common neurodegenerative disease in individuals over 60 years of age $^{1}$. PD ethiopathogenesis involves progressive neuronal loss in the substantia nigra of the midbrain leading to dopamine deficiency. The primary clinical manifestation of PD is characterized by resting tremor, bradykinesia, rigidity and postural instability ${ }^{2,3}$. The definitive diagnosis of PD is confirmed by the presence of Lewy bodies during post mortem pathological examination of the brain ${ }^{4}$.
PD has a complex, multifactorial etiology 5 . Genetic factors play a major role although most cases are sporadic ${ }^{6}$. The familial forms occur in about $10-15 \%$ of patients with $\mathrm{PD}^{7}$ and a small proportion is of Mendelian inheritance ${ }^{8}$.

Mutations in the leucine-rich repeat kinase-2 (LRRK2) gene, predominantly G2019S mutation, have been reported in individuals with autosomal dominant familial $\mathrm{PD}^{9,10}$. The G2019S mutation has an age-dependent variable penetrance ${ }^{11}$ and evidence shows common ancestry ${ }^{12,13}$. It is also found in patients with sporadic forms of $\mathrm{PD}^{8}$ showing clinical manifestations indistinguishable from idiopathic PD.

1Departamento de Neurologia, Universidade de São Paulo, Sao Paulo SP, Brazil;

Laboratório de Genética Molecular, Instituto de Biociências, Universidade de São Paulo, Sao Paulo SP, Brazil.

Correspondence: Hsin Fen Chien; Rua Vergueiro 1421 / cj 1506; 04101-000 São Paulo SP, Brasil; E-mail: chien.74@fmusp.org.br

Conflict of interest: There is no conflict of interest to declare.

Received 14 October 2013; Received in final form 30 December 2013; Accepted 22 January 2014. 
The G2019S mutation occurs in 1-2\% of sporadic cases of PD in Caucasians ${ }^{14,15}$. However, the prevalence varies according to the population studied ranging from less than $0.1 \%^{16}$ to $41 \%$ in North African Arabs ${ }^{17,18}$.

Few studies have assessed specifically the frequency of the G2019S mutation in late-onset sporadic PD patients. Thus, this study aimed to identify the G2019S mutation in a sample of late-onset Brazilian patients with no known family history of PD.

\section{METHOD}

We recruited patients with PD from among those followed up at the neurology outpatient clinic of the Movement Disorders Clinic within Hospital das Clínicas of the Faculdade de Medicina of the Universidade de São Paulo (HC-FMUSP) and at the Brazilian Parkinson Association. We included 100 patients with PD who met the study inclusion criteria.

We recruited 100 age- and gender-matched individuals to the control group. They comprised of patient's spouses and not blood-related caregivers or other patients with no neurological disease attending outpatient clinics of other specialties within the hospital.

\section{Inclusion criteria}

The following eligibility criteria were applied to all individuals participating in the study: male or female patients with clinical diagnosis of PD following the diagnostic criteria established by The United Kingdom Parkinson's Disease Society Brain Research Centre; ${ }^{4}$ onset of PD signs and/or symptoms after the age of 50; being able to understand the information conveyed in the free informed consent form approved by HC-FMUSP institutional review board (CAPPesq) and signing the consent form before entering the study.

\section{Exclusion criteria}

Individuals with known first-degree relatives with PD were ineligible to participate in the study.

\section{Analysis of biological materials}

We collected buccal swab samples with a cotton swab for genetic analysis. The samples of biological materials collected from oral mucosa were stored in standard plastic vials and kept refrigerated until they were sent to the Laboratório de Genética Molecular at the Instituto de Biociências of the Universidade de São Paulo. The samples were stored at $-70{ }^{\circ} \mathrm{C}$ after DNA extraction. The G2019S mutation in the DNA extracted was analysed by polymerase chain reaction (PCR) followed by restriction enzyme digestion ${ }^{19,20}$.

\section{RESULTS}

We examined 100 patients with PD (65 males and 35 females) and 100 controls ( 65 males and 35 females). The mean age of patients and controls was 73.3 (standard deviation $[\mathrm{SD}]=7.8)$ and 71.2 years $(\mathrm{SD}=8.5)$, respectively. The age at onset of $\mathrm{PD}$ symptoms was 64.0 years $(\mathrm{SD}=8.6)$. We used Student's $t$-test to compare the groups and verified that age followed a normal distribution. Most patients and controls were Brazilian-born, but Table shows that many had parents who came from other countries.

The genetic analysis of buccal swab samples to assess the frequency of the LRRK2 G2019S mutation showed no mutations in both patients with PD and controls group.

\section{DISCUSSION}

According to Healy et al., $2008^{21}$, the frequency of the mutation G2019S across the world is $4 \%$ in familial PD and $1 \%$ in sporadic PD cases. However, a higher frequency

Table. General characteristics of patients and controls.

\begin{tabular}{|c|c|c|c|c|c|c|}
\hline & \multicolumn{2}{|c|}{ Patients } & \multirow{2}{*}{$\begin{array}{c}\text { Total } \\
100\end{array}$} & \multicolumn{2}{|c|}{ Controls } & \multirow{2}{*}{$\begin{array}{c}\text { Total } \\
100 \\
\end{array}$} \\
\hline & Male: 65 & Female: 35 & & Male: 65 & Female: 35 & \\
\hline Mean age (years) & 72.6 & 74.9 & 73.3 (SD 7.8) & 70.7 & 72.1 & 71.2 (SD 8.5) \\
\hline Mean age at PD onset (years) & 63.3 & 65.3 & 64.0 (SD 8.6) & N/A & N/A & N/A \\
\hline \multirow{8}{*}{ Country of birth of each parent } & & & 71 Brazil & & & 77 Brazil \\
\hline & & & 8 Japan & & & 10 Italy \\
\hline & & & 5 Italy & & & 3 Portugal \\
\hline & & & 3 Spain & & & 3 Japan \\
\hline & & & 3 Portugal & & & 2 Lebanon \\
\hline & & & 2 China & & & Syria \\
\hline & & & 1 Lebanon & & & 1 Spain \\
\hline & & & 1 Africa/Italy & & & 1 Argentina \\
\hline
\end{tabular}

PD: Parkinson's disease; N/A: not applicable; SD: standard deviation. 
has been reported in North African individuals (36\% in hereditary and 39\% in sporadic PD cases) and Ashkenazi Jews (28\% in hereditary and $10 \%$ in sporadic PD cases). This mutation rarely occurs in Asians.

In the light of the role of the G2019S mutation in the pathophysiology of PD evidenced in molecular studies, and considering that large waves of Portuguese, Spanish, Arab immigrants have settled in Brazil, epidemiological studies are important as they can help to determine the prevalence of the G2019S mutation in the Brazilian population.

In our study, we selected patients with idiopathic and sporadic PD with symptom onset after the age of 50. It is quite hard to describe their demographic specificities since our sampled patients and controls are reflection of Sao Paulo's population, which is composed of a conglomeration of a large number of intertwined ethnic communities. The fact that no mutations were found in this population is an interesting finding given that our sample comprised mostly of Brazilians-born of Italian, Spanish, Portuguese, Japanese, Arab and African ancestry. A multicenter study conducted by Healy et al. ${ }^{21}$ found $4 \%$ frequency of the mutation in sporadic PD cases in Portuguese, 3\% in Spanish and 2\% in Italian individuals.

Earlier Brazilian studies investigating the G2019S mutation have selected familial PD patients with symptom onset before the age of 50 to increase the likelihood of identifying genetic cases. Barsottini et al. ${ }^{22}$ examined 119 patients with PD symptom onset before the age of 50 and found a $3.36 \%$ frequency of the PARK8 gene. Camargos et al. ${ }^{23}$ evaluated a sample of 202 patients with PD symptom onset before the age of 50 and found a familial case with mutation in the LRRK2 gene. Abdalla-Carvalho at al. ${ }^{24}$ studied 204 patients from different nationalities with $\mathrm{PD}$ symptom onset at different ages and found the G2019S mutation in three patients, and in all of them symptom onset was before the age of 50. Aguiar at $\mathrm{al}^{25}$ examined 72 patients with early onset symptoms and reported an incidence rate of $5.5 \%$ of the PARK8 gene. Munhoz et al. ${ }^{26}$ studied 83 Brazilians with early PD onset and found an incidence rate of $3.5 \%$ of the G2019S mutation.

Our results may be explained by the relatively small sample size and selection bias. Another possibility could be due to a lower frequency of the G2019S mutation in the Brazilian population than the $1 \%$ estimated frequency of cases with sporadic PD worldwide. We do not have any comparative studies because the aforementioned studies did not evaluate patients with sporadic PD with symptom onset after the age of 50, they evaluated either familial cases or onset of PD before age of 50 .

Another important consideration about our study is the approach of analyzing genetic materials obtained from buccal swab. The advantages of this method are easy sample collection, low sampling risk (no venipuncture required) and the procedure is not painful which increases the willing of the patients to participate in the study. Lastly, mouth lining scraping requires only a small amount of specimen to perform DNA analysis and have being utilized by some authors previously for the same purpose ${ }^{18,27}$.

Our study examined a sample of 100 patients with sporadic PD with late symptom onset and 100 age- and gender matched controls for the presence of the G2019S mutation. No mutations were found in both patients and controls. This result can be attributed to the relatively small sample size and selection bias. Further studies with larger samples are needed to assess the frequency of this mutation.

\section{References}

1. Lang A, Lozano AM. Parkinson's disease: first of two parts. N Engl J Med 1998;339:1044-1053.

2. Barbosa ER, Limongi JCP, Cummings JL. Parkinson's disease. Psychiatr Clin North Am 1997;20:769-790.

3. Gelb DJ, Oliver E, Gilman S. Diagnostic criteria for Parkinson disease. Arch Neurol 1999;56:33-39.

4. Hughes AJ, Daniel SE, Kilford L, Lees AJ. Accuracy of clinical diagnosis of idiopathic Parkinson's disease: a clinico-pathological study of 100 cases. J Neurol Neurosurg Psychiatry 1992;55:181-184.

5. Farrer MJ. Genetics of Parkinson disease: paradigm shifts and future prospects. Nature Rev 2006;7:306-318.

6. Klein C. Implications of genetics on the diagnosis and care of patients with Parkinson disease. Arch Neurol 2006; 63: 328-334.

7. Bonifati V. The LRRK2-G2019S mutation: opening a novel era in Parkinson's disease genetics. Eur J Hum Gen 2006;14:1061-1062.

8. Gilks, WP, Abou-Sleiman PM, Gandhi S, et al. A common LRRK2 mutation in idiopathic Parkinson's disease. Lancet 2005;365:415-416.

9. Di Fonzo A, Rohe CF, Ferreira J, et al. A frequent LRRK2 gene mutation associated with autosomal dominant Parkinson's disease. Lancet 2005;365:412-415.
10. Di Fonzo A, Tassorelli C, De Mari M, et al. Comprehensive analysis of the LRRK2 in sixty families with Parkinson's disease. Eur J Hum Genet 2006;14:322-331.

11. Goldwurm S, Zini M, Mariani L, et al. Evaluation of LRRK2 G2019S penetrance: relevance for genetic counseling in Parkinson disease. Neurology 2007;68:1141-1143.

12. Goldwurm S, Di Fonzo A, Simons EJ, et al. The G6055A (G2019S) mutation in LRRK2 is frequent in both early and late onset Parkinson's disease and originates from a common ancestor. J Med Genet 2005;42:65.

13. Karchegus J, Mata IF, Hulihan M, et al. Identification of a novel LRRK2 mutation linked to autosomal dominant parkinsonism: evidence of a common founder across European population. Am J Hum Genet 2005;76:672-680.

14. Berg D, Schweitzer KJ, Leitner P, et al. Type and frequency of mutations in the LRRK2 gene in familial and sporadic Parkinson's disease. Brain 2005;128:3000-3011.

15. Schrag A, Schott JM. Epidemiological, clinical, and genetic characteristics of early-onset parkinsonism. Lancet Neurol 2006;5:355-363 
16. Tan EK, Shen H, Tan LCS, et al. The G2019S LRRK2 mutation is uncommon in an Asian cohort of Parkinson's disease patients. Neurosci Lett 2005;384:327-329.

17. Lesage S. Durr A, Tazir M, et al. LRRK2 G2019S as a cause of Parkinson's disease in North African Arabs. N Engl J Med 2006;354:422-423.

18. Ozelius LJ, Senthil G, Saunders-Pullman R, et al. LRRK2 G2019S as a cause of Parkinson's disease in Ashkenazi Jews. N Engl J Med 2006;354:424-425.

19. Richards B, Skoletsky J, Shuber AP, et al. Multiplex PCR amplification from the CFTR gene using DNA prepared from buccal brushes/ swabs. Hum Mol Genet 1993;2:159-163.

20. Hernandez DG, Paisan-Ruiz C, Mclnerney-Leo A, et al. Clinical and positron emission tomography of Parkinson's disease caused by LRRK2. Ann Neurol 2005;57:453-456.

21. Healy DG, Falchi M, O’Sullivan SS, et al. Phenotype, genotype, and worldwide genetic penetrance of LRRK2-associated Parkinson's disease: a case-control study. Lancet Neurol 2008;7:583-590.
22. Barsottini OG, Felício AC, Aguiar PdeC, et al. Clinical and molecular neuroimaging characteristics of Brazilian patients with Parkinson's disease and mutations in PARK2 or PARK8 genes. Arq Neuropsiquiatr 2009;67:7-11.

23. Camargos ST, Dornas LO, Momeni P, et al. Familial parkinsonism and early onset Parkinson's disease in a Brazilian Movement Disorders Clinic: phenotypic characterization and frequency of SNCA, PRKN, PINK1, and LRRK2 mutations. Mov Disord 2009;24:662-666.

24. Abdalla-Carvalho CB, Santos-Rebouças CB, Guimarães BC, et al. Genetic analysis of LRRK2 functional domains in Brazilian patients with Parkinson's disease. Eur J Neurol 2010;17:1479-1481.

25. Aguiar PdeC, Lessa PS, Godeiro C Jr, et al. Genetic and environmental findings in early-onset Parkinson's disease Brazilian patients. Mov Disord 2008;23:1228-1233.

26. Munhoz RP, Wakutani Y, Marras C, et al. The G2019S LRRK2 mutation in Brazilian patients with Parkinson's disease: phenotype in monozygotic twins. Mov Disord 2008;23:290-294.

27. Saunders-Pullman R, Stanley K, Wang C, et al. Olfactory dysfunction in LRRK2 G2019S mutation carriers. Neurology 2011;77:319-324. 